\title{
Total lactic acid bacteria, phenolic compounds and antioxidant activities of pineapple waste and Indigofera zollingeriana leaves by liquid fermentation
}

\author{
Rizki Palupi $^{* 1)}$, Marieska Verawaty ${ }^{2)}$, Fitri Nova Liya Lubis ${ }^{1)}$, Nova Oktarinah ${ }^{1)}$ \\ ${ }^{1)}$ Departement of Technology and Livestock Industry, Faculty of Agricultural, Sriwijaya \\ University, Indralaya \\ ${ }^{2)}$ Departement of Biology, Faculty of Science and Matematic Sriwijaya University. Indralaya, \\ Indralaya.
}

Submitted: 25 November 2018, Accepted: 14 February 2020

\begin{abstract}
This study aims to determine the best combination of pineapple waste liquid fermentation and Indigofera zollingeriana leaves, which produces the highest amount of lactic acid bacteria, the highest vitamin $\mathrm{C}$ content, and total phenols, and the best antioxidant from the combination of the fermentation results. The resulting fermentation product will be used as a natural feed additive in poultry rations. This research was conducted with an experimental method using a Completely Randomized Design (CRD), which consisted of five preparations and four replications. The treatments were combination of pineapple waste and Indigofera zollingeriana leaves: P1 (100\% pineapple waste), P2 (98\% pineapple waste and 2\% Indigofera zollingeriana leaves), P3 (96\% pineapple waste and 4\% Indigofera zollingeriana leaves), P4 (94\% pineapple waste and 6\% Indigofera zollingeriana leaves) and P5 (92\% pineapple waste and $8 \%$ Indigofera zollingeriana leaves). Substrate from each combination of pineapple waste and leaves of Indigofera zollingeriana was fermented with the contribution of $10 \%$ of lactic acid bacteria obtained from commercial yogurt and incubated for 72 hours. The parameters in this study consisted of total lactic acid (Lactobacillus bulgarius), the concentration of vitamin $\mathrm{C}$, total phenols, and antioxidant activity. The results showed that the combination of pineapple waste and Indigofera zollingeriana leaves proved significantly $(\mathrm{P}<0.05)$ to total lactic acid bacteria (Lactobacillus bulgarius), vitamin $\mathrm{C}$ concentration, total phenols and antioxidant activity of the fermented liquid (supernatant) products. In conclusion, the combination of $92 \%$ pineapple waste and $8 \%$ leaves of Indigofera zollingeriana had the highest total bacterial contribution, produced the highest vitamin $\mathrm{C}$ and phenolic compounds, and increased antioxidants.
\end{abstract}

Keywords: antioxidant activity; Indigofera zollingeriana leaves; pineapple waste

*Corresponding Author: palupiarda@yahoo.com 


\section{INTRODUCTION}

The livestock industry is a fastgrowing industry in Indonesia because of the steady growth of poultry meat consumption among people. The increasing need for meat encourages farmers to pay more attention to the quality of products produced and maintain the health status of livestock that are kept. One way that can be done to improve product quality is by adding natural feed additives to animal feed. Natural feed additives generally come from plant ingredients that contain certain active compounds, both as antioxidants and natural antibiotics. The addition of organic acids in drinking water or feed for broiler proved to be able to increase absorption by increasing the function of digestive enzymes so as affect digestion and absorption, especially fiber and protein (Atapattu and Nellisgaswatta, 2005; AbdelFattah et al., 2008).

One way to produce organic acids is to use pineapple waste and leaves of fermented Indigofera zollingeriana by utilizing the lactobacillus bacteria contained in yogurt, the use of yogurt is useful as a source of lactic acid bacteria. In the fermentation process, besides requiring a source of bacteria from yogurt, it also requires a substrate for bacterial growth. A substrate in the fermentation process can be produced from pineapple waste, where pineapple waste contains food substances such as protein, glucose, and fructose (Andriani et al., 2013). Apart from pineapple waste, the use of Indigofera zollingeriana leaves can also be used as a substrate. Palupi et al. (2014) Indigofera zollingeriana leaves contain $28.98 \%$ crude protein and relatively low NPN, which is $2 \%$ so that the leaf protein of Indigofera zollingeriana can be relied upon as a source of Nitrogen. Nitrogen is needed because it can accelerate the growth of lactobacillus bacteria in fermentation.

Fermented fruits and vegetables are known to produce probiotic drinks that contain phenol compounds and have antioxidant functions. Sutedjo (2015) reported that the addition of star fruit $20 \%$ with 8 hours fermentation time resulted in vitamin $\mathrm{C}$ of $0.022 \%$ and the total phenol compound of $1.533 \%$ with antioxidant activity of $50.313 \%$. The results of Widagdha's research (2015) reported that yogurt fermented drinks added by $20 \%$ grape juice with 12 hours fermentation time had a total phenolic compound of $1.17 \%$ with antioxidant activity of $56.475 \%$. Research on the combination of pineapple waste and leaves of Indigofera zollingeriana fermented by the addition of lactic acid bacteria by the utilization of lactobacillus bacteria in yogurt has never been done. Fermented products will be used as acidifiers in poultry diets.

\section{MATERIALS AND METHODS Research material}

The materials or ingredients used in liquid fermentation were pineapple waste, Indigofera zollingeriana leaves, aquades, granulated sugar, Cimory plain yogurt. While the materials used for the analysis of organic acids were aquades, acetic acid, lactic acid, citric acid, $85 \%$ phosphoric acid, $\mathrm{KH}_{2} \mathrm{PO}_{4}$. Additionally, the ingredients used for antioxidant testing were supernatant from fermented pineapple waste and leaves of Indigofera zollingeriana, aquades, DPPH, $5 \% \mathrm{Na}_{2} \mathrm{Co}_{3}$ solution, and methanol.

The tools used in liquid fermentation were a plastic bag, blender, scale, stove, steamer pot, 20 units of 3-liter-capacity plastic jars, paper labels, wooden spoon, and sticky tape. While the tools used for the analysis of organic acids using the HPLC method were HPLC (High-Performance Liquid Chromatograph) tool, pipette, aluminum foil, spoon, magnetic stirrer, 0.2 and $0.45 \mu \mathrm{m}$ Whatman filter paper, plates, desiccator, cup clamp, analytic balance. Furthermore, the tools used for antioxidant testing were spectrophotometer, cuvette, vortex, beaker glass, stirring rods, test tube, and rack. 


\section{Research method}

The study was conducted with an experimental method using a Completely Randomized Design (CRD), which consisted of five treatments and four replications. The treatment in this study was a combination of pineapple waste and Indigofera zollingeriana leaves. The combination of these treatments are:

P1: 100\% fermented fresh pineapple waste

P2: $98 \%$ fermented pineapple waste with $2 \%$ Indigofera zollingeriana leaves

P3: $96 \%$ fermented pineapple waste with $4 \%$ Indigofera zollingeriana leaves

P4: $94 \%$ fermented pineapple waste with $6 \%$ Indigofera zollingeriana leaves

P5: $92 \%$ fermented pineapple waste with $8 \%$ Indigofera zollingeriana leaves

\section{Research conduction procedure}

Pineapple waste fermentation process referred to Nurhayati et al. (2014) was modified using Indigofera zollingeriana leaves. Fresh pineapple waste that had been cleaned and fresh leaves of Indigofera zollingeriana were chopped, then weighed based on the arrangement and then put into a plastic bag. Subsequently, the plastic bag with materials follows the steam process for 30 minutes intended for sterilization. Then, the process was carried out for 10 minutes before, then put into a jar, the fermentation process by adding water to the substrate involving 1:2 w/v, 15 grams of sugar, and yogurt as much as $100 \mathrm{ml} / \mathrm{kg}$. The fermentation incubation time was 72 hours.

During fermentation, an everyday stir was carried out on the fermentation media, and this aimed to homogenize the nutrients in the fermentation media. Next, the separation between the supernatant and the fermented biomass was carried out. Then, the amount of waste biomass of pineapple and leaves of Indigofera zollingeriana formed, and the amount of supernatant containing organic acids was determined after the fermentation process took place. The fermented supernatant was followed by an analysis of the degree of acidity, total lactic acid bacteria, total acid concentration, total phenolic compounds, and antioxidant activity.

\section{Observed variables}

1. Lactic Acid Bacteria Number Test

The LAB test followed the procedure of Hidayat et al. (2013). The plate count method (Total Plate Count) was used to determine the total LAB. The calculation of total LAB was calculated on the planting of Man Rogasa and Sharpe (MRS) media. Calculation of total LAB began with samples diluted in sterile aquades in a ratio of 1:9. Dilutions were carried out from $10^{-1}$ to $10^{-7}$. The cup making was done using MRS agar media. Making MRS of $65.13 \mathrm{~g}$ was dissolved in $1000 \mathrm{ml}$ of distilled water, then dissolved. MRS was a water bath at $95^{\circ} \mathrm{C}$ until it dissolved and sterilized at $121^{\circ} \mathrm{C}$ for 15 minutes.

Preparation of the cup media was carried out with $1 \mathrm{ml}$ of the dilution sample inserted into a Petri dish that already contained MRS agar. The cup making was carried out from a $10^{-6}$ to $10^{-7}$ dilution. Then the cup was moved to form the number 8 so that it was homogeneous. Once stable, the cup was incubated in an upside-down position at $37^{\circ} \mathrm{C}$ for 48 hours and counted the growing colonies using Colony Counter. The total number of colonies counted must meet the ICMF standard, which was between $30-300$ colonies per Petri dish.

2. The concentration of Vitamin C Test

The sample was weighed as much as 10-30 grams, then put into a $100 \mathrm{ml}$ volumetric flask and then added distilled water to the boundary mark. Then the filtrate is homogenized and filtered with filter paper. From the obtained filter, $25 \mathrm{ml}$ was taken and put into $100 \mathrm{ml}$ Erlenmeyer, then, $1 \mathrm{ml}$ of $1 \%$ starch was added to it. The filtrate that was added with starch was titrated with a standard $0.01 \mathrm{~N}$ iodine solution until a color change occurred. Vitamin $C$ levels were calculated using the following formula: 
Vitamin C $(\%)=(\mathrm{ml}$ iodine $\times 0.01 \mathrm{~N} \times 100 / 25 \times 88 \times 100) /$ weight of material $(\mathrm{mg})$.

3. Total Phenol Compounds

Determination

$0.4 \mathrm{~mL}$ sample adds into a $10 \mathrm{ml}$ measuring flask. Then, $0.4 \mathrm{~mL}$ FolinCiocalteu reagent add and well-shaken. After five minutes, $4 \mathrm{~mL}$ of $7 \% \mathrm{Na}_{2} \mathrm{CO}_{3}$ was mixed with aquades until it reached a volume of $10 \mathrm{~mL}$. Incubation was performed for 90 minutes at $23^{\circ} \mathrm{C}$ then absorbance readings were carried out using a spectrophotometer at $\lambda 750 \mathrm{~nm}$ (Lee et al., 2003).

\section{Antioxidant Activity}

The antioxidant activity test used DPPH (Diphenyl Pikril hidrazil) method, according to AOAC (2005), was as follows: Samples were taken as much as 1 $\mathrm{ml}$. The sample solution was made into four series of dilutions, which were 0,5 ,
10, and 15. The sample solution for each dilution was taken from $1 \mathrm{ml}$, then added 9 $\mathrm{ml}$ of methanol to the test tube and homogenized.

Each dilution series was taken $2 \mathrm{ml}$, and then $2 \mathrm{ml} \mathrm{DPPH}$ solution was added and homogenized with a vortex. For the preparation of the DPPH solution, $2 \mathrm{ml}$ of DPPH was taken and dissolved using $2 \mathrm{ml}$ of methanol into a $50 \mathrm{ml}$ measuring flask. DPPH solution was put into a cuvette and then absorbed by spectrophotometer (wavelength $517 \mathrm{~nm}$ ) and recorded as absorbance blank. The vortex solution was left in a dark room for 30 minutes then put into a cuvette, and the absorbance value was measured with a spectrophotometer (wavelength $517 \mathrm{~nm}$ ) and recorded as absorbance of the sample. The formulas used to calculate antioxidant activity are:

$$
\% \text { Inhibition }=\frac{(\mathrm{A} \text { control }-\mathrm{A} \text { sample }) \times 100 \%}{\mathrm{~A} \text { control }}
$$

Note: A control $=$ Absorbance does not contain samples

A sample $=$ Sample absorbance

\section{Data analysis}

Data analysis uses the analysis of variance following the Completely Randomized Design. If there are significant differences in treatment, further tests will use the Duncan Multiple Range Test (Steel and Torrie, 1991).

\section{RESULTS AND DISCUSSION \\ Effect of treatment on the content of lactic acid bacteria}

Lactic acid bacteria observed in liquid products fermented from pineapple waste and Indigofera zollingriana leaves in this study were types of Lactobacillus bulgarius bacteria. The average number of lactic acid bacteria from the combination of pineapple waste and Indigofera zollingriana leaves during fermentation are shown in Table 1. Based on the average number of Lactobacillus bulgarius bacteria in Table 1 , it can be seen that the combination of pineapple waste and leaves of Indigofera zollingeriana influenced the content of lactic acid bacteria fermented. The increasing use of Indigofera zollingeriana leaves in combination with the substrate, further increased the population of the lactic acid bacteria. Indigofera zollingeriana leaf is one of the legume plants that has a high crude protein content, which is $28.98 \%$ and its low NPN content is $2 \%$ (Palupi et al., 2014) so that the leaves of Indigofera zollingeriana have the potential to be a source of Nitrogen for growth lactic acid bacteria during the fermentation process. Okafor (2007) stated that lactic acid bacteria require a carbon source of around $46-52 \%$ and a nitrogen source of $10-14 \%$ and minerals for their growth. 
Table 1. Average of Lactobacillus bulgaricus bacteria of liquid fermented products from pineapple waste and Indigofera zollingeriana leaves.

\begin{tabular}{cc}
\hline Treatment & Amount of Lactobacillus bulgaricus bacteria $(\mathrm{CFU} / \mathrm{mL})$ \\
\hline P1 & $6,5 \times 10^{4}$ \\
P2 & $9,1 \times 10^{6}$ \\
P3 & $1,7 \times 10^{7}$ \\
P4 & $8,4 \times 10^{8}$ \\
P5 & $2,3 \times 10^{8}$ \\
\hline
\end{tabular}

Winarsih (2005) stated that not all bacteria could be used as probiotics. Several requirements must be fulfilled, including having antimicrobial and anticarcinogenic activity, being able to colonize the digestive tract, and being able to increase intestinal absorption. Some types of probiotics that are often used are Bifidobacterium brevis, $B$. infantis, $B$. longu, Lactobacillus acidopholus, $L$. bulgaricus, L. plantarum, L. rhamnosus, $L$. casei, and Streptococcus thermophilus. This probiotic product is marketed or sold in the form of milk and food supplements.

The results of this study are in line with some of the results of research on fermentation of pineapple juice production and the manufacture of probiotic drinks, including the results of research by Elsaputra et al. (2016) that pineapple skin fermentation produced the content of lactic acid bacteria $7.08 \times 107$ cells $/ \mathrm{ml}$ with a $\mathrm{pH}$ of 3.94. Tambunan's research results (2016) stated that the content of lactic acid bacteria of pineapple juice after fermentation was $1.1 \times 108 \mathrm{CFU} / \mathrm{ml}$, with a $\mathrm{pH}$ of 5.67. Rizal et al. (2016) state that the best lactic acid bacterial strain is Lactobacillus casei, which produces a $\mathrm{pH}$ of 3.54 with a bacterial amount of 1.1 x $1010 \mathrm{CFU} / \mathrm{ml}$. Then Angrestian et al. (2014) reported that the initial population of lactobacillus bacteria in the manufacture of antibiotic drinks was $6.5 \times 104 \mathrm{CFU} / \mathrm{ml}$ and increased to $9.8 \times 108 \mathrm{CFU} / \mathrm{ml}$.

\section{Treatment effect on the concentration of vitamin $C$ and phenol compounds}

The average vitamin concentration of liquid product fermented from pineapple waste and leaves of Indigofera zollingriana are shown in Table 2.

Table 2. The average concentration of vitamin $\mathrm{C}$ and phenolic compounds of liquid fermented products from pineapple waste and Indigofera zollingeriana leaves.

\begin{tabular}{ccc}
\hline Treatment & Vitamin C Concentration $(\%)$ & Total Phenolic Compounds \\
\hline P1 & $0,10 \pm 0,01^{\mathrm{a}}$ & $1,95 \pm 0,31^{\mathrm{a}}$ \\
P2 & $0,20 \pm 0,05^{\mathrm{a}}$ & $3,15 \pm 0,35^{\mathrm{b}}$ \\
P2 & $0,66 \pm 0,07^{\mathrm{b}}$ & $3,03 \pm 0,48^{\mathrm{b}}$ \\
P4 & $0,69 \pm 0,07^{\mathrm{b}}$ & $3,93 \pm 0,23^{\mathrm{c}}$ \\
P5 & $0,66 \pm 0,07^{\mathrm{b}}$ & $4,18 \pm 0,10^{\mathrm{c}}$ \\
\hline
\end{tabular}

Note: Numbers followed by different letters in the same column show significant differences $(\mathrm{P}<0,05)$.

The results of the analysis of variance showed that the combination of pineapple waste and leaves of Indigofera zollingeriana had a significant effect $(\mathrm{P}$ $<0.05$ ) on the concentration of vitamin $\mathrm{C}$ of fermented liquid products (supernatants). The significant effect happens because of the higher content of Indigoferaa zollingeriana leaves improves the population of lactic acid bacteria in the fermentation results. Concerning the increase in Lactobacillus bulgaricus bacteria with vitamin $\mathrm{C}$ content, it can be seen that the bacteria produce acidic conditions that could increase the level of vitamin $\mathrm{C}$ itself. The phenomenon is 
similar to the opinion of Gaman and Sherrington (1994), that cooked fruits will lose less vitamin $C$ than vegetables because their presence is more acidic so that the speed of oxidation is reduced. Also, the sour taste caused by Lactobacillus bulgaricus activity is possible for the presence of vitamin $\mathrm{C}$.

Based on the results of further tests of treatments, P3, P4, and P5 showed that the treatment containing the highest content of vitamin $\mathrm{C}$ was due to the increased use of leaves of Indigofera zollingeriana. While treatment P1 and P2 contain lower content of vitamin $\mathrm{C}$, because the population of Lactobacillus bacteria in the treatment is also lower, so the amount of lactic acid produced is less than the treatments of P3, $\mathrm{P} 4$, and $\mathrm{P} 5$.

The results of Silalahi's research (2009) reported that Lactobacillus bulgaricus had been known to play an essential role in producing high lactic acid in the manufacture of fruitghurt. The principle of making fruitghurt is fruit fermentation using bacteria. Good fruitghurt has a total lactic acid of about $0.85-0.89 \%$ and a degree of acidity $(\mathrm{pH})$ of around 4.5. Sutedja and Nisa (2015) reported that the addition of star fruit in making yogurt increased the total acid and vitamin $\mathrm{C}$ content of the yogurt produced. Based on the analysis of variance on the total concentration of phenol compounds in liquid products that the combination of pineapple waste and Indigofera zollingeriana leaves had a significant effect ( $\mathrm{P}<0.05)$ on the total phenol compounds produced because of the increasing use of Indigofera zollingeriana leaves in the substrate that increased the number of lactic acid bacteria in the fermentation product, thus increasing the change in carbohydrate substrate by these bacteria and increasing phenol compounds produced at the end of fermentation.

The fermentation process, by the addition of Saccharomyces sereviceae inoculants in the substrate, increases the phenol compounds produced (Asngat et al., 2011; Kunaepah, 2008). Pineapple waste fermentation results with Saccharomyces sereviceae as much as producing a total phenol compound of $3.7 \%$ (Melani, 2012)

\section{Effect of treatment on antioxidant activity}

The average antioxidant activity of liquid fermented products from pineapple waste and Indigofera zollingeriana leaves is shown in Table 3.

Table 3. The Average of antioxidant activity of liquid fermented products from pineapple waste and Indigofera zollingeriana leaves.

\begin{tabular}{cc}
\hline Treatment & Antioxidant Activity $(\%)$ \\
\hline P1 & $51,77 \pm 0,55^{\mathrm{b}}$ \\
P2 & $51,60 \pm 3,59^{\mathrm{b}}$ \\
P3 & $47,71 \pm 1,71^{\mathrm{a}}$ \\
P4 & $48,29 \pm 0,03^{\mathrm{a}}$ \\
P5 & $45,37 \pm 1,34^{\mathrm{a}}$ \\
\hline
\end{tabular}

Note: Numbers followed by different letters in the same column show significant differences $(\mathrm{P}<0,05)$

Antioxidants found in pineapple skin fibers included in the group of polyphenol compounds are antioxidants that have several phenol functional groups. This type of antioxidant prevents the oxidation process through the mechanism of capturing free radicals. Thus, the concentration of oxidants and antioxidants in the body remains balanced (Mahyanti, 2007). Then the antioxidant of the liquid product also comes from beta-carotene, which is found in the leaves of Indigofera zollingeriana. Palupi et al. (2014) reported that Indigofera $\mathrm{sp}$. contains beta-carotene compounds of $507.8 \mathrm{mg} / \mathrm{kg}$, which is a source of antioxidants. In addition to beta- 
carotene, Indigofera zollingeriana leaves also contain tannins. Tannins are watersoluble phenolic compounds, which come from vascular plants with molecular weights of 500 to 3000 grams $/ \mathrm{mol}$.

These compounds are widely distributed in leaves, fruit, bark, and stems, generally taste astringent. Tannins have biological activities as chelating metal ions, biological antioxidants, and are antibacterial compounds (Suwandi, 2012). The increasing proportion of Indigofera zollingeriana leaves in the fermented substrate increased the antioxidant activity of the fermented liquid product because of the higher carbohydrate breakdown process by lactic acid bacteria into phenol compounds in the fermentation product. In line with Hurr et al. (2014) that the increased concentration of phenol compounds causes an increase in antioxidant activity.

The antioxidant activity produced in the fermentation products of pineapple and Indigofera zollingeriana leaves is caused by probiotic bacteria producing lactic acid. Lactic acid contains $\alpha$-hydroxy acids (AHA) that function as antioxidants and are often used for the manufacture of cosmetics and in food products ( $\mathrm{Yu}$ and Van Scott, 2002). Apart from lactic acid, which is the main result of metabolism, probiotic bacteria also produce compounds that act as antioxidants.

These antioxidant compounds are secondary metabolites produced by probiotic bacteria.

\section{CONCLUSION}

Based on the results of the study, as the use of Indigofera zollingeriana leaves in a combination of pineapple waste substrate increased, the more the population of lactic acid bacteria, the concentration of vitamin $\mathrm{C}$, the total phenolic compounds of liquid fermented products that contained pineapple waste and Indigofera zollingeriana leaves increased, as well as antioxidant content of the product that is seen from the increasingly decreased antioxidant activity in a combination of $92 \%$ pineapple waste and $2 \%$ Indigofera zollingeriana leaves, which amounted to $45.37 \%$.

\section{REFERENCES}

Abdullah, A., \& Mat, H. (2008). Characterisation of solid and liquid pineapple waste. Reaktor, 12(1), 48-52. https://doi.org/10.14710/reaktor.12.1.48-52

Abdullah, L., \& Suharlina. (2010). Herbage yield and quality of two vegetative parts of indigofera at different times of first regrowth defoliation. Media Peternakan, 33(1), 44-49.

Andriani, R., Akeprathumchai, S., Laoteng, K., Poomputsa, K., Mekvichitsaeng, P., Farmasi, A. A., \& Malang, M. (2013). Utilization of pineapple juice base growth medium for lipid production by xanthophyllomyces dendrorhous. Jurnal Teknologi Pertanian, 14(3), 193-200.

AOAC. (2005). Official Methods of Analysis. United State of America.

Caesarita, D. (2011). Pengaruh Ekstra Buah Nanas (Ananascomosus) 100\% terhadap Bakteri Staphylacoccus aureus dari pioderma. Universitas Diponerogo.

Damayanti, \& Oktavia. (2010). Pabrik Asam Sitrat dari Nira Siwalan Dengan Proses Submerged Fermentation. ITS.

Ginting, S. P., Krisnan, R., \& Tarigan, A. (2005). The Substitution Of Forages With Pineapple Wastes In Complete Feed For Goats. Seminar Nasional Teknologi Peternakan Dan Veteriner, 604-610.

Hatam, S. F., Suryanto, E., \& Abidjulu, J. (2013). Aktivitas antioksidan dari ekstrak kulit nanas (Ananas comosus (L) Merr). PHARMACON Jurnal Ilmiah Farmasi, 2(01), 7-12.

Isfahlan, A. J., Mahmoodzadeh, A., Hassanzadeh, A., Heidari, R., \& Jamei, R. (2010). Antioxidant and antiradical activities of phenolic extracts from Iranian almond (Prunus 
amygdalus L.) hulls and shells. Turkish Journal of Biology, 34(2), 165-173. https://doi.org/10.3906/biy0807-21

Litchfield, J. (2009). Lactic Acid, Microbially Produced. Elsevier Inc.

Mahyanti, \& Surliana, E. (2007). Studi Pendahuluan analisis Bubuk Kulit Buah Nanas (Ananascomocuc L) Sebagai Sumber Dietary Fiber dan Senyawa Antioksidan. Universitas Indonesia.

Mardalena. (2012). Evalusi Pakan Suplemen Sebagai Sumber Antioksidan dan Pengaruhnya Terhadap Respon Fisiologis dan Produktifitas Kambing Perah Peranakan Etawah. Unand.

Muchtadi, T., \& Ayustaningwarno, F. (2010). Teknologi Proses Pengolahan Pangan. Institut Pertanian Bogor Press.

Nour, V., Trandafir, I., \& Ionica, M. E. (2010). HPLC organic acid analysis in different citrus juices under reversed phase conditions. Notulae Botanicae Horti Agrobotanici ClujNapoca, 38(1), 44-48. https://doi.org /10.15835/nbha3814569

Nurhayati, N. (2013). Penampilan ayam pedaging yang mengkonsumsi pakan mengandung tepung kulit nanas disuplementasi dengan yoghurt. Jurnal Agripet, 13(2), 15-20. https:// doi.org/10.17969/agripet.v13i2.814

Nurhayati, N., Nelwida, N., \& Berliana, B. (2014). Pengaruh tingkat yogurt dan waktu fermentasi terhadap kecernaan in vitro bahan kering, bahan organik, protein, dan serat kasar kulit nanas fermentasi. Buletin Peternakan, 38(3), 182-188. https://doi.org/10.21 059/buletinpeternak.v38i3.5254

Palupi, R., Abdullah, L., D A, A., \& Sumiati. (2014). Potensi dan pemanfaatan tepung pucuk Indigofera sp . sebagai bahan pakan substitusi bungkil kedelai dalam ransum ayam petelur. Jurnal Ilmu Ternak Dan Veteriner, 19(3), 210-219.
Prasetyo, M. N., Sari, N., \& Budiyati, C. S. (2012). Pembuatan kecap dari ikan gabus secara hidrolisis enzimatis mengunakan sari nanas. jurnal teknologi kimia dan industri, 1(1), 270-276. https://ejournal3.undip.ac.id /index.php/jtki/article/view/936

Sabahannur, S. (2018). Peningkatan Kadar Alkohol ,Asam dan Polifenol Limbah Cairan PulP Biji Kakao Dengan Penambahan Sukrosa dan Ragi. Universitas Muslim Indonesia.

Saleh, M. A., Clark, S., Woodard, B., \& Deolu-Sobogun, S. A. (2010). Antioxidant and free radical scavenging activities of essential oils. Ethnicity and Disease, 20(1 SUPPL.1), 78-82.

SRUAMSIRI, S. (2007). Agricultural wastes as dairy feed in Chiang Mai. Animal Science Journal, 78(4), 335341. https://doi.org/10.1111/j.17400929.2007.00445.x

Suprihatin. (2010). Teknologi Fermentasi. UNESA Press.

Sutetjo, K. S., \& Nisa, F. (2015). Konsentrasi sari belimbing (Averrhoa carambola $L$ ) dan lama fermentasi terhadap karakteristik fisiko-kimia dan mirobiologi yoghurt. Jurnal Pangan Dan Agroindustri, 3(2), 582-593.

Tarigan, A., Abdullah, L., Ginting, S., \& Permana, I. (2010). Produksi dan komposisi nutrisi serta kecernaan in vitro Indigofera sp pada interval dan tinggi pemotongan berbeda. JITV, 15, 188-195.

Theron, M. M., \& Lues, J. F. R. (2010). Organic Acids and Food Preservation. In The Journey of Chemistry. CRC Press.

Wardhana, R., Sutardi, Rahardjo, T., \& Suryapratama, M. (2013). Fermentasi ampas tebu (Bagasse) menggunakan Phanerochaete chrysosporium sebagai upaya meningkatkan kecernaan bahan kering dan kecernaan bahan organik secara in vitro. Jurnal Ilmiah Peternakan, Vol 1, No 2 (2013): Jurnal Ilmiah 
Peternakan. http://jos.unsoed.ac.id/in dex.php/jip/article/view/624

Winarsi, H. (2007). Antioksidan Alami dan Radikal Bebas. In Potensi dan aplikasinya dalam kesehatan. Penerbit Kanisius.

Winarsih, W. (2005). Pengaruh Probiotik dalam Pengendalian Salmonellosis Subklinis pada Ayam: Gambaran Patologis dan Performan. Sekolah Pascasarjana Institut Pertanian Bogor.
Yu, R. J., \& Scott, E. J. Van. (2002). Hydroxycarboxylic Acids, N Acetylamino Sugars, and N Acetylamino Acids. SKINmed, 1(6), 117-122. https:// doi.org/10.1111/j.1 540-9740.2002.01646a.x

Zuhra, C. F., Tarigan, J. B., \& Sihotang, H. (2008). Aktivitas antioksidan senyawa flavonoid dari daun katuk (Sauropus androgunus (L) Merr.). Jurnal Biologi Sumatra, 3(1), 10-13. 